\title{
Immunotherapy of genital warts with inosine pranobex and conventional treatment: double blind placebo controlled study
}

\author{
J DAVIDSON-PARKER, * W DINSMORE, $\dagger$ M H KHAN, $\ddagger$ D A HICKS,§ \\ C A MORRIS, \| D F MORRIS\|
}

From the *Prince of Wales's Hospital, London; the †Royal Victoria Hospital, Belfast; $\ddagger$ Leighton Hospital, Crewe; the §District General Hospital, Barnsley; and the \|Royal Shrewsbury Hospital, Shrewsbury

SUMMARY In a multicentre, prospective, randomised, placebo controlled study of 55 patients with histories of genital warts for at least one year, a four week course of inosine pranobex $3 \mathrm{~g}$ a day improved the clinical response to conventional treatment (primarily podophyllin or trichloroacetic (now called trichlorethanoic) acid).

Although more patients given inosine pranobex improved than those given placebo, the difference in general response between the two groups was not significant. When other variables (numbers of warts and extent of lesions) were considered, however, the patients given inosine pranobex fared significantly better.

These results suggest that inosine pranobex may be worth considering as adjunct to treatment of patients with refractory genital warts.

Several treatments are available for managing patients with genital warts. They include the topical application of podophyllin ${ }^{1}$ or trichloroacetic (now called trichlorethanoic) acid, cryotherapy, ${ }^{2}$ electrocautery, ${ }^{2}$ or carbon dioxide laser. None of these methods of treatment, however, is uniformly successful.

The persistence of genital warts may be associated with a defective immune response. ${ }^{34}$ Immunomodulating agents have been evaluated in patients with genital warts. Several studies have shown that inosine pranobex is effective in patients with human papillomavirus infection of the genital areas. ${ }^{5-8}$ Mohanty and Scott reported that the best response was obtained when inosine pranobex was used as an adjunct to more conventional treatment regimens, such as podophyllin. ${ }^{5}$

All the studies reported to date can be criticised for their design, as none was double blind or incorporated a placebo treatment group. We report here a prospective, multicentre, double blind, placebo controlled study conducted to assess whether inosine pranobex improved the efficacy of conventional treatment of patients with genital warts.

Address for reprints: Dr J Davidson-Parker, Department of Genitourinary Medicine, Prince of Wales's General Hospital, London N15 4AW.

Accepted for publication 8 April 1988

\section{Patients, materials, and methods}

We conducted the study at five centres in the genitourinary medicine departments of hospitals in the United Kingdom. As one centre served patients at three hospitals, we saw patients at seven hospitals. We studied men and women aged over 18 who had anogenital warts and histories of genital warts for at least one year. We excluded homosexual men with perianal warts; women who were pregnant, breast feeding, or not using adequate contraception; and patients with hyperuricaemia or a history of gout, or who were receiving immunosuppressive or cytotoxic treatment. Other concurrent genitourinary diseases were treated before entry into the study. Patients gave informed consent before participating in the study.

The conventional treatment used was that used routinely in the departments concerned. In addition, patients were randomly selected to receive a 28 day course of inosine pranobex $1 \mathrm{~g}$ three times a day or an indistinguishable placebo (lactose) medication. Separate randomisation lists were used for men and women. The code was broken centrally by Leo Laboratories.

Patients were scheduled to be seen after being treated for two and four weeks and at further follow up eight and 12 weeks after entering the study. At each clinic attendance the following data were recorded: the 
location of each lesion was indicated on a diagram; the number of warts was assessed and recorded as either $1-5,6-10$, or more than 10 ; and the extent of the lesions was recorded as being minimal $(1 \mathrm{~cm}$ in diameter), moderate (more than $1 \mathrm{~cm}$, but less than $2 \mathrm{~cm}$ ), or extensive (more than $2 \mathrm{~cm}$ in diameter).

The general condition of patients in response to treatment was graded as being much improved, improved, unchanged, or worse at each clinic attendance. The number of new lesions arising during and after treatment with inosine pranobex or placebo was also noted. All adverse effects reported spontaneously by the patients or observed by the investigators were recorded.

Statistical analysis was performed using the $\chi^{2}$ test with Yates's correction.

\section{Results}

Of 55 patients who entered the study, four from different centres were not assessed: two because they failed to reattend their clinic, one woman stopped treatment after only one week because of nausea and a suspicion that she was pregnant, and another patient took the medication for only two weeks, because the bottle containing the tablets was stolen. Of the remaining 51, 24 (14 men, 10 women) were given inosine pranobex and 27 (17 men, 10 women) received placebo. The two treatment groups were comparable regarding history of infection with warts and previous treatment; number, site, and type of warts present; and the conventional treatment used. More patients receiving placebo than inosine pranobex had minimal lesions, but the difference was not significant.

Poor follow up was a major feature of the study. Twenty seven patients (14 receiving active treatment, 13 placebo) attended all four follow up visits, 11 (six receiving active treatment, five placebo) attended on three occasions, eight (two receiving active treatment, six placebo) were assessed twice, and five (two receiving active treatment, three placebo) made only one follow up visit. Inadequate follow up was greatest at the Prince of Wales's Hospital, London, where 23/76 planned clinic visits were missed, and the Royal Shrewsbury Hospital, where 5/16 planned clinic visits were missed. Fewest $(2 / 44)$ visits were missed at the Royal Victoria Hospital, Belfast. Attendance was worse in patients receiving placebo, who missed $26 / 108$ of the planned clinic visits compared with $16 / 96$ planned clinic visits missed by patients receiving inosine pranobex. Because of this, two methods of analysis were performed.

Firstly, we analysed all 51 patients who attended at least one follow up visit. This method of analysis can be criticised as the reasons for poor clinic attendance, or for continuing to visit the clinic, might have been different in the two treatment groups and could have biased the results either in favour of, or against, one particular treatment. Assessment of the general response at the visit before the first missed appointment indicated that more $(8 / 10)$ patients receiving inosine pranobex had shown an improvement than those receiving placebo $(7 / 14)$. The condition of more patients receiving placebo was unchanged or had

Table 1 Demographic data of patients analysed (figures are numbers of patients except where stated)

\begin{tabular}{|c|c|c|c|c|}
\hline & \multicolumn{2}{|c|}{ No attending at least one follow up visit } & \multicolumn{2}{|c|}{ No attending all follow up visits } \\
\hline & $\begin{array}{l}\text { Inosine pranobex } \\
(n=24)\end{array}$ & $\begin{array}{l}\text { Placebo } \\
(n=27)\end{array}$ & $\begin{array}{l}\text { Inosine pranobex } \\
(n=14)\end{array}$ & $\begin{array}{l}\text { Placebo } \\
(n=13)\end{array}$ \\
\hline Men & 14 & 17 & 9 & 9 \\
\hline Women & 10 & 10 & 5 & 4 \\
\hline Mean age (years) & $25 \cdot 8$ & $25 \cdot 6^{*}$ & $25 \cdot 4$ & $24 \cdot 7^{*}$ \\
\hline Mean duration of warts (months) & $18 \cdot 2$ & $19 \cdot 3$ & $17 \cdot 1$ & $14 \cdot 5$ \\
\hline \multicolumn{5}{|l|}{ Previous treatment: $\dagger$} \\
\hline None & 3 & 5 & $2 \ddagger$ & 1 \\
\hline Podophyllin & 18 & 20 & $10^{+}$ & 12 \\
\hline Trichloroacetic acid & 9 & 12 & 7 & 8 \\
\hline Surgery & 12 & 11 & 8 & 9 \\
\hline \multicolumn{5}{|l|}{ Number of warts: } \\
\hline $1-5$ & 5 & 7 & 4 & 5 \\
\hline $6-10$ & 6 & 8 & 4 & 5 \\
\hline$>10$ & 13 & 12 & 6 & 3 \\
\hline \multicolumn{5}{|l|}{ Extent of lesions: } \\
\hline Minimal & 5 & 11 & 4 & 9 \\
\hline Moderate & 10 & 6 & 5 & 1 \\
\hline Extensive & 9 & 10 & 5 & 3 \\
\hline \multicolumn{5}{|l|}{ Treatment given: } \\
\hline Podophyllin & 16 & 18 & 7 & 4 \\
\hline Trichloroacetic acid & 11 & 12 & 8 & 11 \\
\hline Surgery & 2 & 2 & 1 & 1 \\
\hline
\end{tabular}

*Not recorded for one patient.

†Previous treatment not recorded for one patient. Some patients had received multiple treatment previously. 
Immunotherapy of genital warts with inosine pranobex and conventional treatment

Table 2 General response to treatment of 51 patients with genital warts who attended at least one follow up visit

\begin{tabular}{|c|c|c|c|c|c|c|c|c|c|c|}
\hline \multirow[b]{2}{*}{ Week } & \multicolumn{5}{|c|}{ Inosine pranobex $(n=24)$} & \multicolumn{5}{|c|}{ Placebo $(n=27)$} \\
\hline & $\begin{array}{l}\text { No } \\
\text { attending }\end{array}$ & $\begin{array}{l}\text { Much } \\
\text { improved }\end{array}$ & Improved & Unchanged & Worse & $\begin{array}{l}\text { No } \\
\text { attending }\end{array}$ & $\begin{array}{l}\text { Much } \\
\text { improved }\end{array}$ & Improved & Unchanged & Worse \\
\hline $\begin{array}{r}2 \\
4 \\
8 \\
12\end{array}$ & $\begin{array}{l}22 \\
22 \\
18 \\
18\end{array}$ & $\begin{array}{r}6 \\
8 \\
8 \\
11\end{array}$ & $\begin{array}{r}11 \\
10 \\
9 \\
4\end{array}$ & $\begin{array}{l}5 \\
2 \\
1 \\
2\end{array}$ & $\begin{array}{l}0 \\
2 \\
0 \\
1\end{array}$ & $\begin{array}{l}25 \\
24 \\
15 \\
18\end{array}$ & $\begin{array}{l}3 \\
2 \\
5 \\
5\end{array}$ & $\begin{array}{r}12 \\
15 \\
6 \\
5\end{array}$ & $\begin{array}{l}8 \\
5 \\
3 \\
5\end{array}$ & $\begin{array}{l}2 \\
2 \\
1 \\
3\end{array}$ \\
\hline
\end{tabular}

deteriorated.

Secondly, we analysed only the 27 patients who attended all of the follow up visits. Table 1 shows the demographic data of all patients.

\section{PATIENTS ATTENDING AT LEAST ONE FOLLOW UP VISIT \\ General response to treatment}

Table 2 shows the general response to treatment. More patients receiving inosine pranobex than placebo showed an improvement at all the follow up visits, but this was only significant $(p<0.05)$ for much inproved patients four weeks after treatment $(8 / 22 v 2 / 24)$.

\section{Number of warts present}

Differences were also seen between the two treatment groups in relation to the reduction in the number of warts present. The number of patients given inosine pranobex with fewer warts varied from $7 / 22$ at week 2 to $14 / 18$ at week 12 . Corresponding figures for patients receiving placebo were $7 / 25$ at week 2 and $7 / 15$ at week 8 .

\section{Extent of lesions}

Reduction in the extent of lesions was also greater at all assessments of patients given inosine pranobex than in those given placebo. Significantly $(\mathrm{p}<0.05)$ more patients given inosine pranobex than placebo had a reduction both at the end of the treatment $(10 / 22$ $v 3 / 25)$ and on completion of follow up (14/18 v6/18).

\section{Development of new lesions}

Similar numbers of patients in the two treatment groups developed new lesions during both treatment and follow up.

Table 3 General response to treatment of 27 patients with genital warts who attended all follow up visits

\begin{tabular}{|c|c|c|c|c|}
\hline \multirow[b]{2}{*}{ Week } & \multicolumn{2}{|c|}{ Inosine pranobex $(n=14)$} & \multicolumn{2}{|c|}{ Placebo $(n=13)$} \\
\hline & $\begin{array}{l}\text { Much } \\
\text { improved }\end{array}$ & Improved & $\begin{array}{l}\text { Much } \\
\text { improved }\end{array}$ & Improved \\
\hline $\begin{array}{r}2 \\
4 \\
8 \\
12\end{array}$ & $\begin{array}{l}5 \\
4 \\
7 \\
9\end{array}$ & $\begin{array}{l}6 \\
7 \\
6 \\
2\end{array}$ & $\begin{array}{l}2 \\
1 \\
5 \\
4\end{array}$ & $\begin{array}{l}6 \\
8 \\
5 \\
4\end{array}$ \\
\hline
\end{tabular}

PATIENTS ATTENDING ALL FOLLOW UP VISITS

Of the 51 patients analysed 27 attended all four follow up visits (table 1). Fourteen of them took inosine pranobex, and placebo tablets were given to 13 . The two treatment groups were well matched, although there was a tendency for the placebo group to contain more patients with minimal lesions.

\section{General responses to treatment}

Table 3 shows that more patients given inosine pranobex than placebo responded, although the difference was not significant. At the end of the study, 11 of the 14 patients receiving active treatment had responded, compared with eight out of the 13 receiving placebo. Complete cures were achieved in five patients receiving active treatment and three receiving placebo.

\section{Number of warts present}

Conventional treatment supplemented by inosine pranobex had a significant effect in completely eradicating the warts by the end of the study period $(5 / 14 v 3 / 13 ; p<0.05)$. The number of patients who had fewer warts by the end of the study was greater in those receiving active treatment $(10 / 14)$ than placebo $(7 / 13)$.

\section{Extent of lesions}

A significant reduction in the extent of lesions at the end of the study compared with the classifications on entry was seen only in patients receiving inosine pranobex $(p=0.05)$. Lesion extent was reduced in 11 receiving inosine pranobex and five receiving placebo.

\section{Development of new lesions}

New lesions developed during the study in six out of the 14 patients taking inosine pranobex compared with 11 out of the 13 taking placebo. This difference was not significant.

\section{ADVERSE EFFECTS}

Adverse effects were reported by only two patients, one in each treatment group. A woman taking inosine pranobex experienced nausea and stopped treatment as there was also the possibility that she might be pregnant, though subsequent tests did not confirm the pregnancy. A woman taking the placebo tablets 
complained of persistent abdominal pain, which was aggravated by food.

\section{Discussion}

Although several previously published studies have found inosine pranobex to be effective in patients with genital warts, both when used alone ${ }^{68}$ or as an adjunct to other methods of treatment, ${ }^{57}$ the natural history of genital warts is unpredictable and many patients show spontaneous regression.

The results we obtained indicate that, in patients with a long history of genital warts, a four week course of $3 \mathrm{~g}$ inosine pranobex a day can improve significantly the efficacy of conventional treatment. More patients given inosine pranobex experienced a reduction in both the number of warts present and the extent of the lesions and showed overall clinical improvement.

The total cure we obtained $(36 \%, 5 / 14)$ using inosine pranobex and conventional treatment was less than the $95 \%$ reported by Mohanty and Scott, ${ }^{5}$ although our mean general improvement of $82 \%$ was similar to theirs. The criteria used to select patients for this study and the methods of assessing the response to treatment, however, were more rigorous than those that can be used routinely in a busy clinic.
Homosexual male patients were excluded as far as possible from this trial, as we considered that their demographic and sexual characteristics would be more suitable for a separate study.

This study was supported by Leo Laboratories Ltd, Aylesbury, Buckinghamshire.

\section{References}

1 Simmons PD. Podophyllin $10 \%$ and $25 \%$ in the treatment of ano-genital warts. A comparative double-blind study. British Journal of Venereal Diseases 1981;57:208-9.

2 Simmons PD, Langlet F, Thin RNT. Cryotherapy versus electrocautery in the treatment of genital warts. British Journal of Venereal Diseases 1981;57:273-4.

3 Mohanty KC, Roy RB. Thymus derived lymphocytes (T cells) in patients with genital warts. British Journal of Venereal Diseases 1984;60:186-8.

4 Pyrhonen S, Johansson E. Regression of warts: an immunological study. Lancet 1975; ;:592-5.

5 Mohanty KC, Scott CS. Immunotherapy of genital warts with inosine pranobex (Imunovir): preliminary study. Genitourin Med 1986;62:352-5.

6 Malgouyat J. A new approach to the treatment of genital condyloma in women. Gynaecologie 1983;34:415-7.

7 Sadoul G, Beuret TH. Treatment of cervical and vulvar condylomata by carbon dioxide laser and an immunostimulant. Rev Fr Gynecol Obstet 1984;79:681-4.

8 Bilhaut JP, Dusard L-F. Colposcopical study of uterine neck condyloma latum and treatment with Isoprinosine. Gynaecologie 1986;37:91-7. 